[13] Turchyn, I. M., Hamkalo, Kh., Voichyshyn, A. (2017). Use of whey in the production of dessert. Scientific Messenger of LNU of Veterinary Medicine and Biotechnologies, 19 (80), 165-168

[14] Katz, G., Merin, U., Bezman, D., Lavie, S., Lemberskiy-Kuzin, L., Leitner, G. (2016). Real-time evaluation of individual cow milk for higher cheese-milk quality with increased cheese yield. Journal of Dairy Science, 99 (6), 4178-4187. doi: 10.3168/jds.2015-10599

[15] Ferrao, L. L., Silva, E. B., Silva, H. L. A., Silva, R., Mollakhalili, N., Granato, D. et. al. (2016). Strategies to develop healthier processed cheeses: Reduction of sodium and fat contents and use of prebiotics. Food Research International, 86, 93-102. doi: 10.1016/j.foodres.2016.04.034

[16] Ha, M., Sabherwal, M., Duncan, E., Stevens, S., Stockwell, P., McConnell, M. et. al. (2015). InDepth Characterization of Sheep (Ovis aries) Milk Whey Proteome and Comparison with Cow (Bos taurus). PLOS ONE, 10 (10), e0139774. doi: 10.1371/journal.pone.0139774

[17] Kaminarides, S., Nestoratos, K., Massouras, T. (2013). Effect of added milk and cream on the physicochemical, rheological and volatile compounds of Greek whey cheeses. Small Ruminant Research, 113 (2-3), 446-453. doi: 10.1016/j.smallrumres.2013.04.009

[18] Gachak, Yu. R., Gutyj, B. V., Benitska, A., Dyakun, T., Pristantsky, R., Kinitska, L. (2017). Use of «Amarant» cryoproush in the technology of dairy products of treatment and propofilactic degradation. Scientific Messenger of LNU of Veterinary Medicine and Biotechnologies, 19 (80), 57-62. doi: 10.15421/nvlvet8012

[19] Vysochina, G. V. (2013). Amaranth (Amaranthus 1.): Chemical composition and prospects of using (Review). Chemistry of plant raw material, 2, 5-14. doi: 10.14258/jcprm.1302005

\title{
OBTAINING AND CHARACTERISTIC OF THE AUTOLYSATE OF LACTIC ACID BACTERIA
}

\author{
Antonina Kapustian \\ Department of Food Chemistry \\ Odessa National Academy of Food Technologies \\ 112 Kanatna str., Odessa, Ukraine, 65039 \\ foodchem.onaft@gmail.com \\ Natalia Cherno \\ Department of Food Chemistry \\ Odessa National Academy of Food Technologies \\ 112 Kanatna str., Odessa, Ukraine, 65039 \\ cherno.onaft@gmail.com
}

\begin{abstract}
Fragments of bacterial peptidoglycan relating to compounds of the muropeptide series have high biological activity. They have an immunological effect, due to the fact that they are signals for immune receptors and, accordingly, their activators. In order to obtain fragments of peptidoglycans, the autolysis of the bacterial mass Lactobacillus delbrueckii subsp. Bulgaricus 2-11 was performed and the characteristics of protein nature products of autolysate were given. To obtain cell suspensions at different growth stages, a growth curve of the bacterial culture was constructed for 48 hours. The autolysis of biomass was carried out at the end of the logarithmic phase of growth at the temperatures $37-90{ }^{\circ} \mathrm{C}$ and after the stationary phase of growth at the temperatures $37-90$ ${ }^{0} \mathrm{C}$ for 7 days. The degree of autolytic changes was evaluated by the definition of colony forming units, the accumulation of amino acids, low molecular weight peptides and soluble protein in the autolysate. The results of studies of autolytic biomass changes have shown that the largest accumulation of amino acids occurs in autolysate, which was obtained at the end of the logarithmic phase of the growth of bacterial mass at exposures at $90{ }^{\circ} \mathrm{C}$. The molecular-mass composition of protein nature compounds of the autolysate soluble fraction is determined. It is established that peptides with a molecular weight in the range corresponding to the molecular weight of the muropeptides are presented in the autolystate, but their quantity is rather insignificant.
\end{abstract}

Keywords: lactic acid bacteria, bacteriocins, autolysis, autolysate, peptidoglycan, muropeptide. 


\section{Introduction}

Lactic acid bacteria (LAB) are unique microorganisms that are used in various fields of human activity: medicine, genetic engineering, food technology, agriculture. LAB are responsible for the equilibrium state of microbiocenosis of the human gastrointestinal tract and for the state of its immune status $[1,2]$.

Fragments of peptidoglycans of LAB cell walls - muropeptides - are able to initiate a signaling cascade of reactions and enhance the immune response of a weakened organism in the course of infection with certain pathogens [3-5].

Obtaining of muropeptides is a quite difficult task, since the bulk of the LAB belongs to Gram-positive bacteria, the peptidoglycan part in which can reach $70 \%$. This is the main obstacle to its fragmentation [6].

Peptidoglycans of gram-positive bacteria are complex biopolymers, which are a multi-layered rigid lattice and quite resistant to the action of degrading factors: physical, chemical, enzymatic [1]. In order to receive muropeptides or the primary degradation of LAB cell walls, one should not neglect the fact that the LAB are producers of bacteriocin, which can lead to autolysis and degradation of their own cells. Bacteriocins are antimicrobial polypeptides synthesized ribosomp ally by bacteria. Most bacteriocins from lactic acid bacteria exert their antibacterial effect by permeabilizing the target cell membrane, whereby the cells lose their viability. Apart from damaging cell membranes, some bacteriocins have also been reported to cause bacteriolysis [7]. The scheme of structural organization and destruction of peptidoglycan of LAB cell walls by bacteriocins is depicted on Fig. 1.

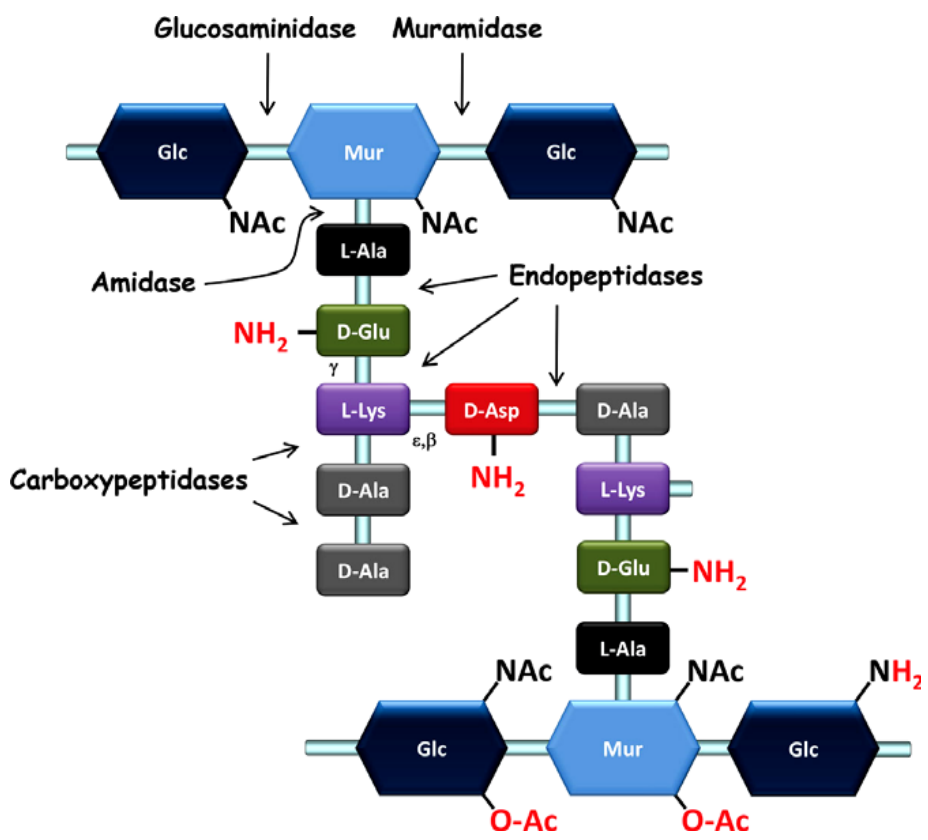

Fig.1. The scheme of structural organization and destruction of peptidoglycan of LAB cell walls [1]

As a rule, in the production of probiotic products or products that are manufactured using lactic acid fermentation should strive to avoid the processes of autolysis. In this paper, it is proposed to consider the process of autolysis from the opposite point of view, namely, as a desirable positive effect for the destruction of LAB cell walls and the production of immunological fragments of peptidoglycan $[8,9]$.

The purposes of the work are modeling and research of the autolysis process of lactic acid bacteria biomass Lactobacillus delbrueckii subsp. Bulgaricus B-3964, the characterization of autolysis products. This will make it possible to understand how deep the degradation of the structural components of the peptidoglycan of these microorganisms occurs under autolysis. Also, the results of the studies will make it possible to understand whether autolytic biomass changes 
are sufficient to obtain immunological compounds of the muropeptide series having a molecular weight $<1500$ Da.

\section{Materials and Methods of the autolysis process Lactobacillus delbrueckii subsp. Bulgaricus 2-11}

\section{1. Materials}

The strain Lactobacillus delbrueckii subsp. Bulgaricus B-3964 from the collection of Scientific and production enterprise "Ariadna", Odessa (Ukraine) was maintained in $12 \%$ sterile recona stituted skim milk (RSM) supplemented with $2 \%$ glucose (Fluka RdH, Buchs, Switzerland) and $1 \%$ yeast extract (Fluka RdH, Buchs, Switzerland) and stored at $-80{ }^{\circ} \mathrm{C}$. Working cultures were prepared from frozen cultures by three successive transfers in $12 \%(\mathrm{w} / \mathrm{v})$ low-heat RSM before use, and stored at $4 \circ \mathrm{C}$. Bacterial strain was grown at $37^{\circ} \mathrm{C}$ without shaking [10].

\section{2. Experimental procedures}

In order to obtain cell suspensions at different growth stages, a growth curve of the bacterial culture was constructed for 48 hours. For this purpose, the cultures were inoculated with the Koch method at intervals of one hour. The concentration of bacterial cells was determined by seeding tenfold dilutions on the surface of the MCA agar medium and expressed in colony forming units in $1 \mathrm{~cm}^{3}\left(\mathrm{CFU} / \mathrm{cm}^{3}\right)$. The growth curve of the bacterial mass is shown in Fig. 2.

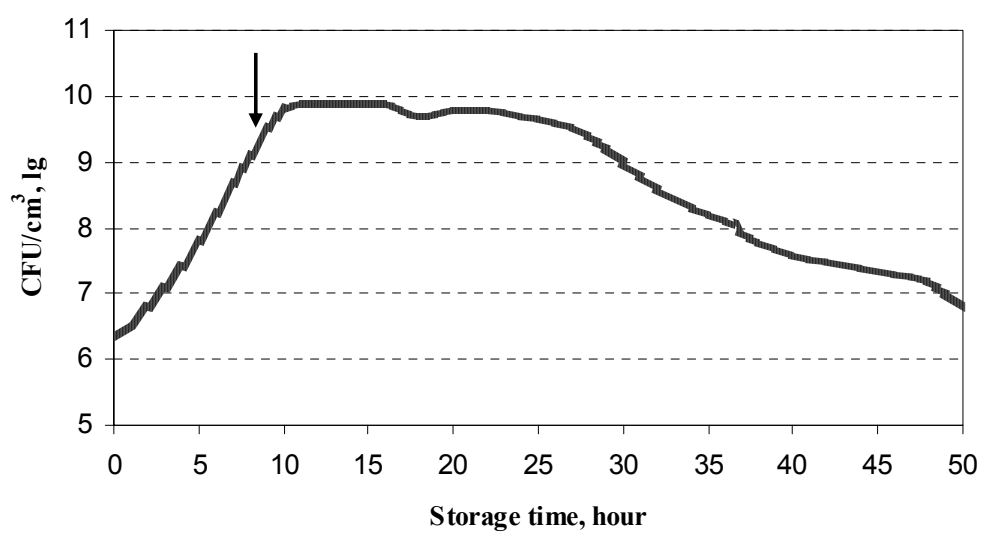

Fig. 2. The growth curve Lactobacillus delbrueckii subsp. Bulgaricus B-3964

The autolytic enzyme system exhibits its greatest activity during the exponential growth phase and is not detectable during the stationary phase [10,11]. Therefore, BM autolysis was carried out at the end of the logarithmic phase of growth at the temperatures of $37-90{ }^{\circ} \mathrm{C}$ (after eight hours of cultivation) and after stationary growth phase (24 hours of cultivation), maintaining it at the temperatures of $37-90{ }^{\circ} \mathrm{C}$ for 7 days.

The autolysates were cooled to the room temperature after exposure, centrifuged for $10 \mathrm{~min}$ at $8000 \mathrm{~min}^{-1}$, then decantation was performed. In the supernatant, the content of free amino acids was controlled by the method of formolithic titration [12], soluble protein by Benedict's method [12], low-molecular-weight peptides by the Benedict method after precipitation of high molecular-weight proteins by $10 \%$ solution of trichloroacetic acid. It is known that peptides with a molecular weight of up to $1500 \mathrm{Da}$ are not precipitated by trichloroacetic acid solutions and are compounds having high immunological activity [13].

In order to determine the molecular weight composition of soluble protein substances, autolysate was centrifuged for $10 \mathrm{~min}$ at $8000 \mathrm{~min}^{-1}$, then decantation was performed. The supernan tant was subjected to ion exchange chromatography to remove neutral sugars and anions.

The purification of the autolysate protein substances was carried out by ion-exchange chromatography using KU-2 cation exchanger. To activate the cation exchanger, $10 \mathrm{~g}$ of KU-2 was shaken for 60 minutes with $300 \mathrm{~cm}^{3}$ of $1 \mathrm{~N} \mathrm{HCl}$, after which it was washed with distilled water until neutral reaction. As a result of this treatment, the cation exchanger is saturated with 
$\mathrm{H}^{+}$ions. The ion exchanger was then shaken with water and transferred to a chromatographic column $(\mathrm{H}=30 \mathrm{~cm}, \mathrm{D}=1.8 \mathrm{~cm})$, in the lower part of which a small tampon of glass wool was pre-inserted.

$50 \mathrm{~cm}^{3}$ of the supernatant was passed through the column at the rate of $1 \mathrm{~cm}^{3} / \mathrm{min}$. When the solution is passed, electrically neutral molecules (sugars, etc.) and anions are not absorbed by the column. Amino acids, peptides and proteins are adsorbed by the cation exchanger, exchanging for $\mathrm{H}^{+}$ions. The column was then washed with $40 \mathrm{~cm}^{3}$ of distilled water and proceeded to elute the adsorbed cations. Elution was carried out by passing a column of $50 \mathrm{~cm}^{3}$ of $6 \mathrm{~N} \mathrm{NH}_{4} \mathrm{OH}$ at the rate of about $1 \mathrm{~cm}^{3} / \mathrm{min}$. The column was then washed with $30 \mathrm{~cm}^{3}$ of water. The eluate was evaporated in a water bath, than $30 \mathrm{~cm}^{3}$ of water was added and again evaporated to remove traces of ammonia. The principle of the ion exchange column is shown in Fig. 3.

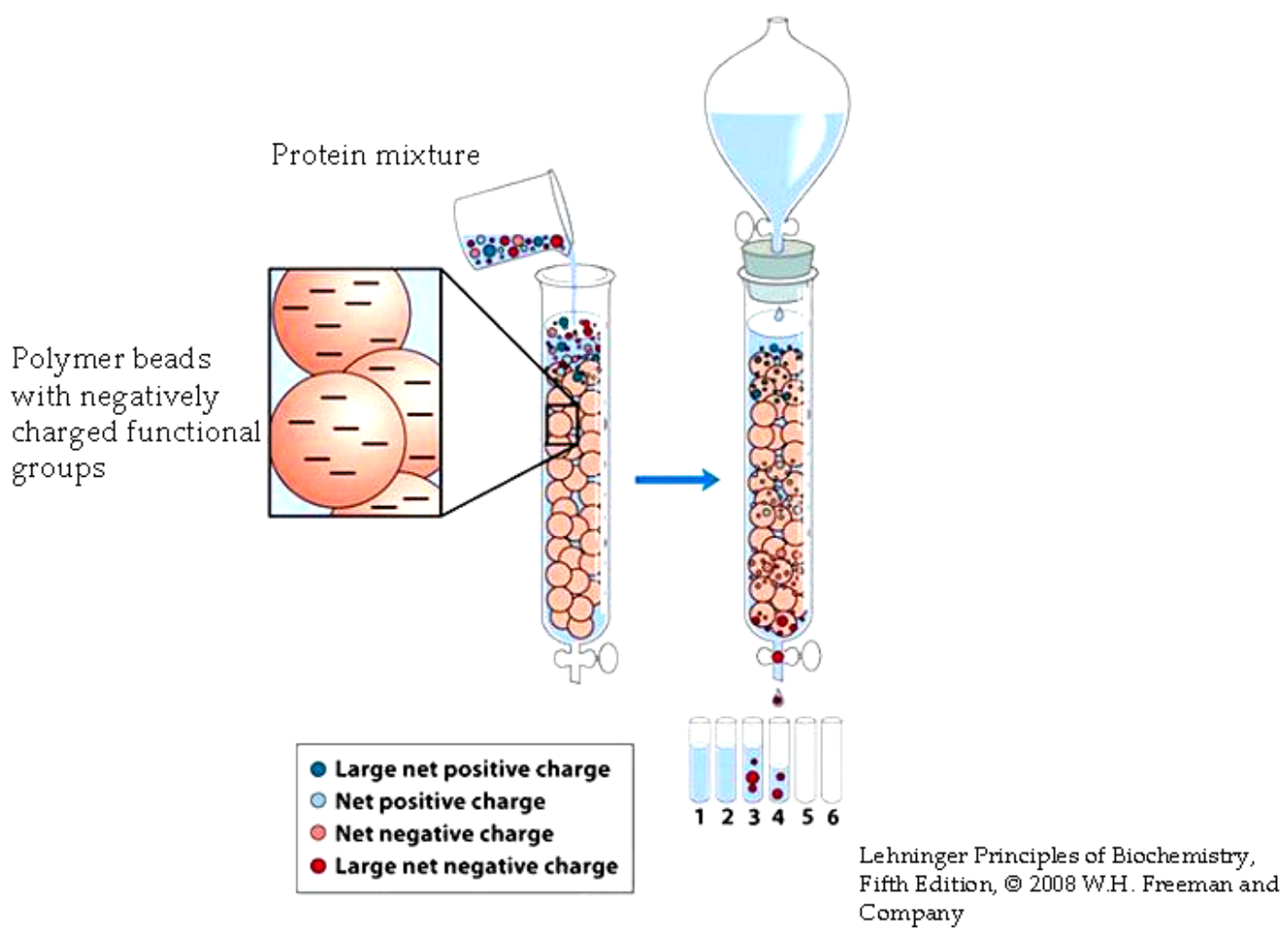

Fig. 3. The scheme of ion exchange column operation [14]

The molecular weight composition of the mixture of protein nature compounds of autolysate was determined by gel-chromatography on columns with Sephadex G-15 and G-150. Sephadexes were soaked for swelling with 20-30 times the volume of distilled water for 12-48 hours at the room temperature, than supernatant decantation_was carried out. This process was repeated until the water over the Sephadex was transparent. The Sephadex suspension was then shaken with water and transferred to column in the lower part of which a small tampon of glass wool was pre-inserted. The principle of the gel-chromatography column is shown in Fig. 4.

$1 \mathrm{~cm}^{3}$ of the test solution at a concentration of $5-10 \mathrm{mg} / \mathrm{cm}^{3}$ was gently applied on the surt face of the gel Eluent was water. Fractions were then taken at $2 \mathrm{~cm}^{3}$. The content of protein nature compounds was determined by Benedict's method.

The column $\mathrm{G}-15\left(\mathrm{H}=28 \mathrm{~cm}, \mathrm{D}=2,8 \mathrm{~cm}, \mathrm{~V}=112 \mathrm{~cm}^{3}\right)$ was calibrated by markers with known molecular weight, namely: I - GMDP (glucosaminylmuryl dipeptide) (MW 650 Da), II - aspartame (L-Aspartyl-L-phenylalanine, MW 294 Da), III - glycine (MW 75 Da). The column G-150 $\left(\mathrm{H}=38 \mathrm{~cm}, \mathrm{D}=3,8 \mathrm{~cm}, \mathrm{~V}=121 \mathrm{~cm}^{3}\right)$ was calibrated by markers I - phosphorylase $(97 \mathrm{kDa})$, II - bovine serum albumin (65 kDa), III - egg albumin (45 kDa), IV - carbohydrase (30 kDa), V lactalbumin (14 kDa). The molecular distribution of markers is depicted in Fig. 5, $\boldsymbol{a}, \boldsymbol{b}$. 


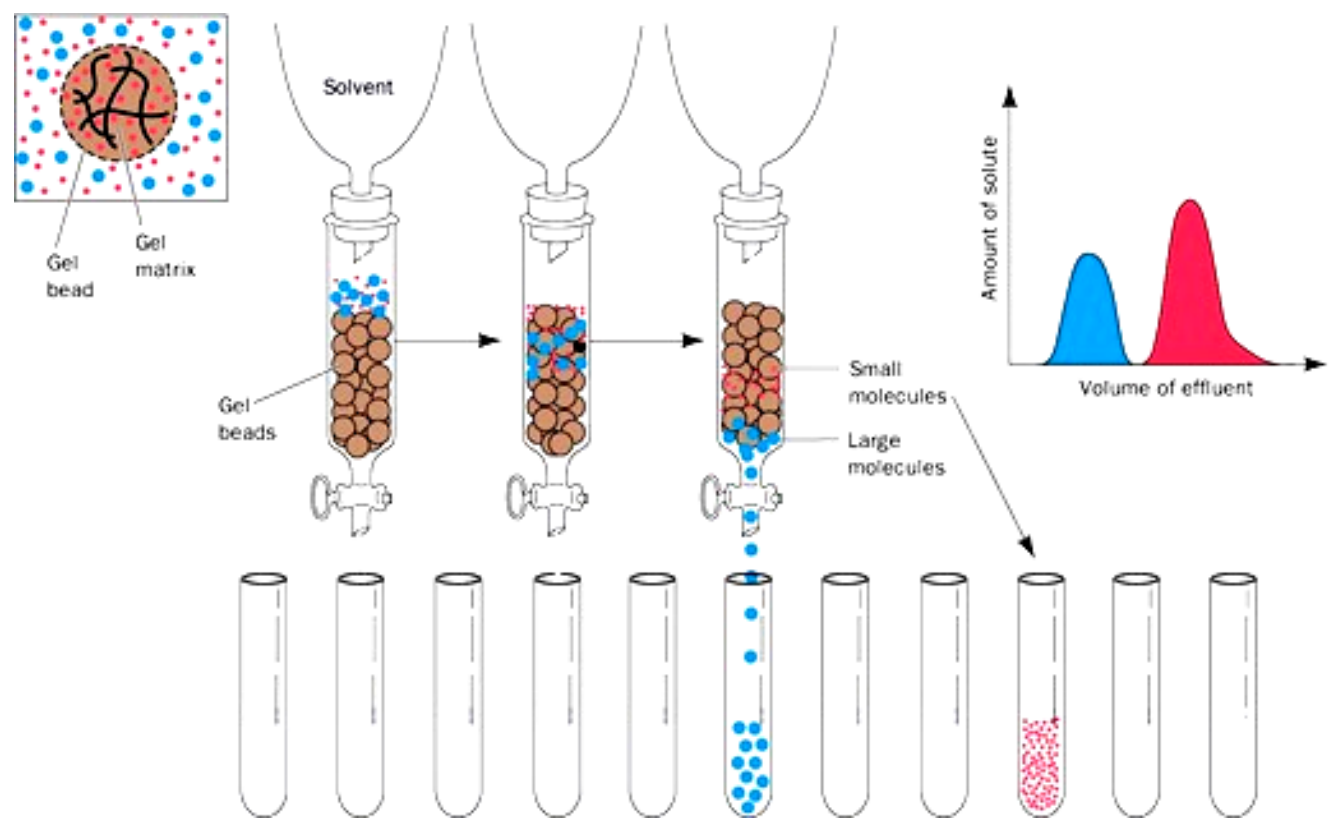

Fig. 4. The scheme of gel-chromatography column operation [15]

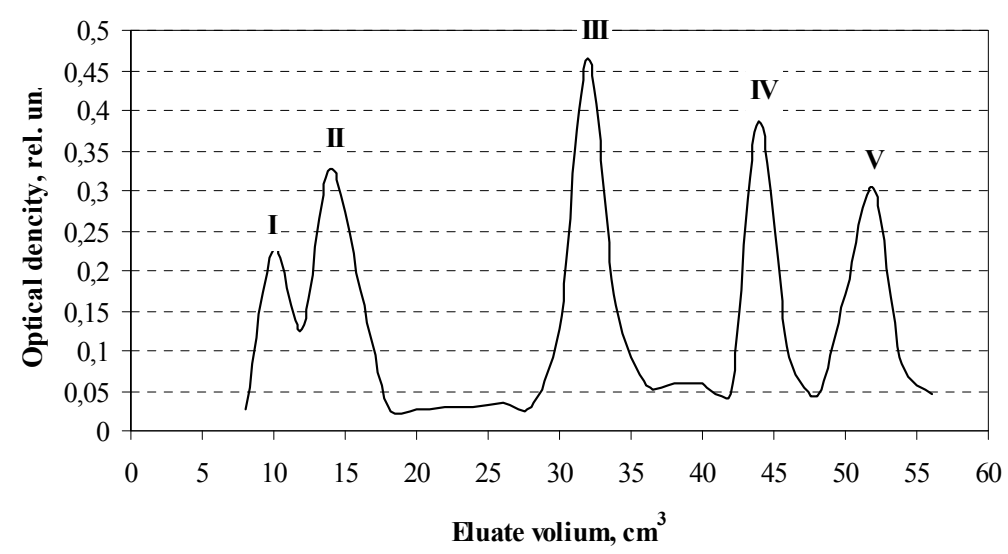

a

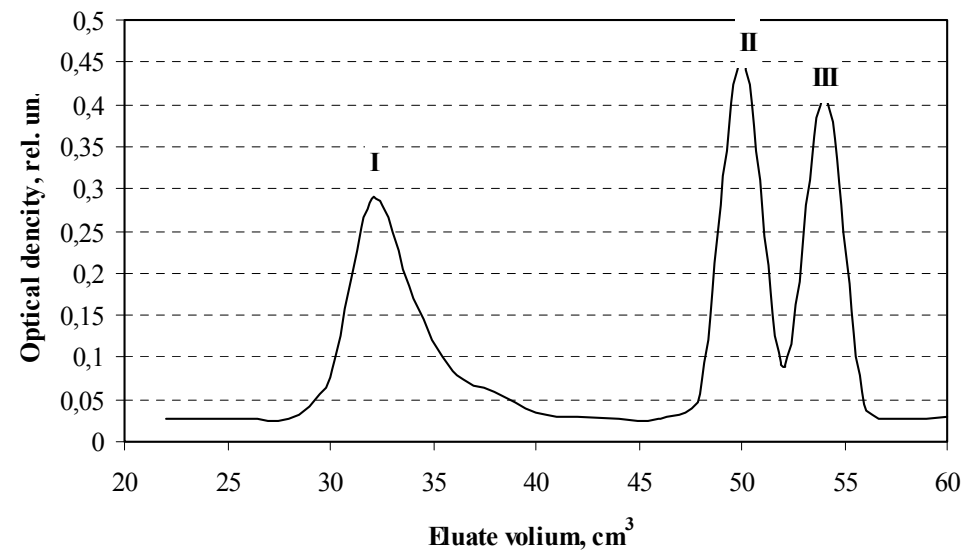

b

Fig. 5. Gel-chromatography curve with markers:

$a$ - column with Sephadex G-150; $b$ - column with sSphadex G-15 
3. Results of the study of the autolysis process of biomass Lactobacillus delbrueckii subsp. Bulgaricus B-3964 and characteristic of protein nature compounds of autolysate

Investigation of autolytic changes of LAB biomass when stored at $37{ }^{\circ} \mathrm{C}$ has been shown that over time, there is a gradual decrease in CFU of LAB. So, at the beginning of the experiment, the number of CFU were $5 \cdot 10^{9}$, and on the seventh day of the exposure already $7 \cdot 10^{4}$ (Fig. 6). Thus, the number of viable cells decreased by almost 2-fold. Biomass, which does not have a colony-bearing capacity, is a potential source for obtaining fragments of peptidoglycans from their cell walls.

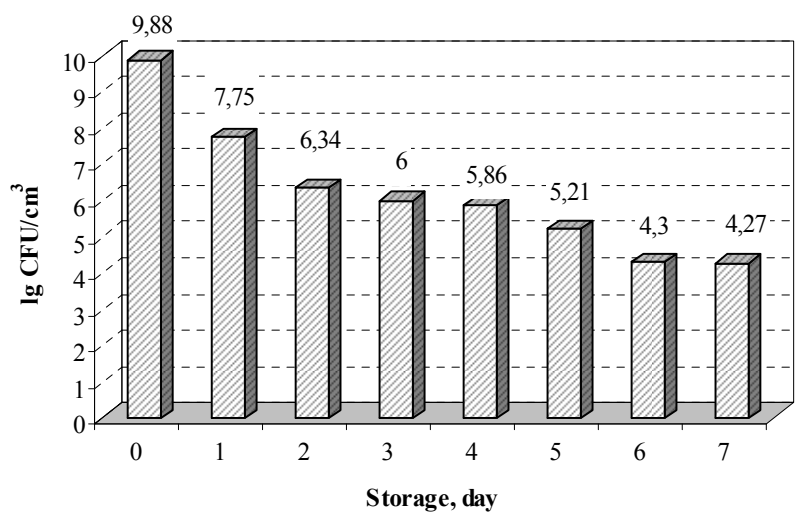

Fig. 6. Dynamics of changes in the CFU of Lactobacillus delbrueckii subsp. Bulgaricus B-3964 during storage

One of the simplest and most accessible methods for detecting of the destruction degree of bacterial cells is a definition of the free amino acids content. The dependence of the accumulation of amino acids in the medium of autolysates on the temperature and duration of the process are depicted in Fig. 7.

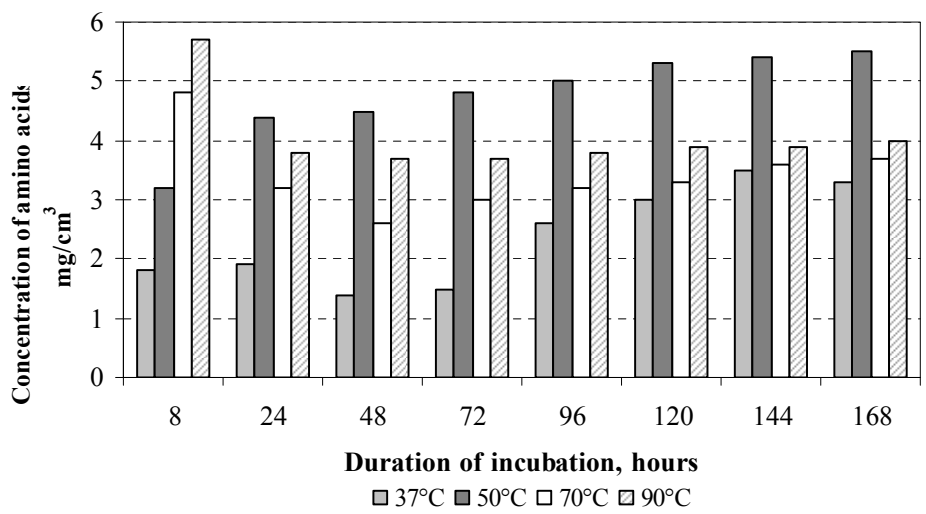

Fig. 7. Comparative dynamics of accumulation of amino acids in autolysates at different exposure temperatures

The results of the research in Fig. 6 demonstrated that the largest accumulation of amino acids occurs in the autolysate, which was obtained at the end of the logarithmic phase of the growth of the bacterial mass at exposures at the temperature of $90^{\circ} \mathrm{C}$. In the autolysis of biomass after the stationary phase, the increase of amino acids in the reaction medium is linear in different incubation temperatures. The maximum content of amino acids occurs when exposed to samples at the temperature of $50{ }^{\circ} \mathrm{C}$.

At the next stage, the molecular-weight composition of the proteinaceous compounds of the autolysate obtained after 8 hours of biomass cultivation at the temperature of $90{ }^{\circ} \mathrm{C}$ for 30 minutes 
was determined to detect the structural components of cell walls of the MB corresponding to the molecular weight of the compounds of the muepeptide series (up to $1500 \mathrm{Da}$ ).

The liquid phase of the autolysate was previously subjected to ion exchange chromatography in order to deprive from the by-products of degradation, metabolites or nutrients of the culture medium. The results of investigations of the autolysate liquid phase on the Sephadex G-150 gel-chromatography column show (Fig. 8) the presence of three main protein fractions in it, as evidenced by the presence of three distinct peaks on the gel chromatographic curve corresponding to fractions of molecular weight within the limits of $70-90 \mathrm{kDa}, 30-40 \mathrm{kDa}$ and a fraction whose molecular weight is less than $14 \mathrm{kDa}$.

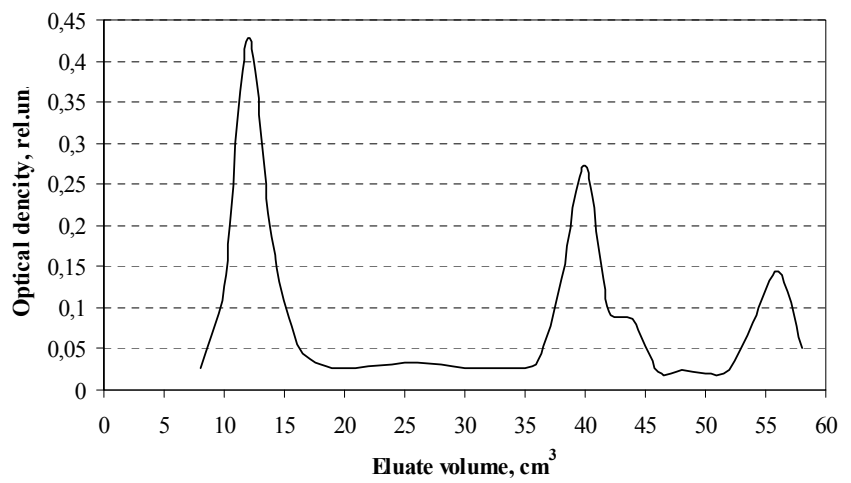

Fig. 8. Gel-chromatography curve of autolysate on the column with Sephadex G-150

For a more detailed study of the latter fraction, at the next stage, its molecular-mass distribution was investigated (Fig. 9).

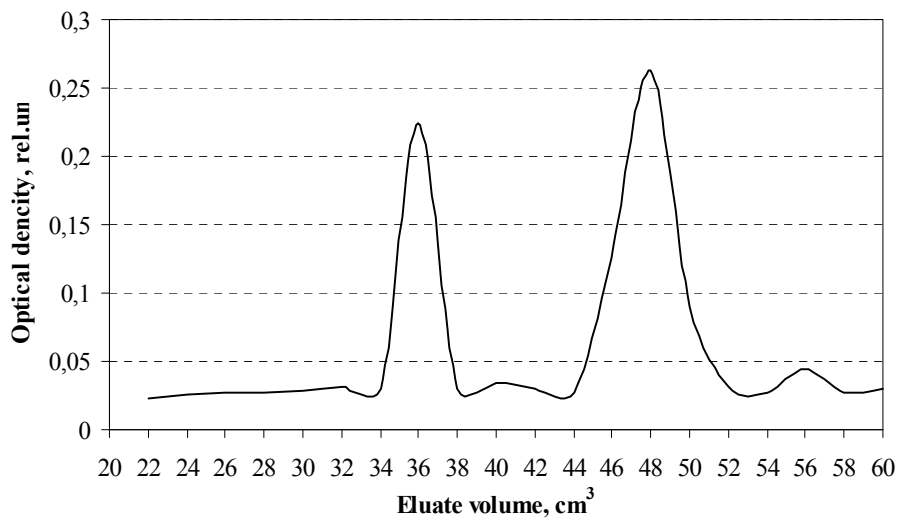

Fig. 9. Gel-chromatography curve of low molecular weight component of autolysate on column with Sephadex G-15

There are two pronounced peaks on the gel chromatographic curve of the low molecular weight fraction of autolysate on the $36 \mathrm{th}, 50 \mathrm{th} \mathrm{cm}^{3}$ of elute, which are between the peaks of markers with molecular weights of 294-650 Da (Fig. 5, b). The results of the studies allow us to state that in the autolysate there are peptides of molecular weight in the range corresponding to the molecular weight of the muropeptides, but their number is rather small.

\section{Conclusions}

1. Autolysis processes of biomass Lactobacillus delbrueckii subsp. Bulgaricus B-3964 at the end of the logarithmic and after the stationary phase of growth are significantly differentiated. The autolysis is most effective at the end of the logarithmic phase of biomass growth at the temperature of $90^{\circ} \mathrm{C}$. This is, obviously, due to the fact that during this period, biomass is most vulnerable to the effects of external stress [7]. After the stationary phase of growth, the autolysis of biomass also 
takes place, but the maximum accumulation of free amino acids occurs at incubation at the temperature of $50-70{ }^{\circ} \mathrm{C}$, which may be due to the activation of the action of bacterial autolysins and the partial denaturation of the protein component.

2. The results of the study of the molecular weight composition of the protein mixture are shown that high molecular weight fractions of protein products have been dominated in the composition of the autolysate. They should be subjected to further transformation in order to obtain degradation products with a higher content of compounds of the muropeptide series.

3. Thus, it has been proven that the use of autolytic processes of biomass leads to a decrease in the CFU of biomass Lactobacillus delbrueckii subsp. Bulgaricus B-3964 and partial degradation of the peptidoglycan of their cell wall. This process is expediently used as a primary stage of destruction of the cell walls of lactic acid bacteria. To obtain samples with a higher content of compounds of the muropeptide series with a molecular weight of less than $1500 \mathrm{Da}$, additional biochemical or chemical factors of influence must be used. Less aggressive is the enzymatic treatment of autolysate by mureidases and peptidases, and the use of specific bacteriophages is also possible.

4. The disadvantage of this study can be considered as the specificity of selected modes relative to a specific LAB strain. When using other monocultures of LABs or LAB compositions, the results of autolytic changes may differ from those given in this paper. The effectiveness of destruction will depend on the composition of the nutrient medium for the cultivation of the LAB, the conditions of cultivation, the characteristics of certain strains of microorganisms, the conditions of autolysis, etc.

\section{References}

[1] Chapot-Chartier, M.-P., Kulakauskas, S. (2014). Cell wall structure and function in lactic acid bacteria. Microbial Cell Factories, 13, 9. doi: 10.1186/1475-2859-13-s1-s9

[2] Glushanova, N. A. (2003). Biologicheskie svoystva laktobatsill. Bulletin of Siberian Medicine, $4,50-58$.

[3] Moreira, L. O., Zamboni, D. S. (2012). NOD1 and NOD2 Signaling in Infection and Inflammation. Frontiers in Immunology, 3. doi: 10.3389/fimmu.2012.00328

[4] Kawai, T., Akira, S. (2010). The role of pattern-recognition receptors in innate immunity: update on Toll-like receptors. Nature Immunology, 11 (5), 373-384. doi: 10.1038/ni.1863

[5] Harris, G. (Ed.) (2008). How the Immune System Recognizes Self and Nonself. Immunoreceptors and Their Signaling. Dordresht: Springer, 251. doi: 10.1007/978-4-431-73884-8

[6] Shaphaev, E. G., Tsyirenov, V. Zh., Chebunina, E. I. (2015). Dezintegratsiya kletok v biotehe nologii. Ulan-Ude, 96.

[7] Martinez-Cuesta, M. C., Kok, J., Herranz, E., Pelaez, C., Requena, T., Buist, G. (2000). Requirement of Autolytic Activity for Bacteriocin-Induced Lysis. Applied and Environmental Microbiology, 66 (8), 3174-3179. doi: 10.1128/aem.66.8.3174-3179.2000

[8] Kapustyan, A. I., Cherno, N. K. (2015). Prospects for using bioactive bacterial hydrolysates for nutritional supplementation of people with immune system disorders. Journal of Food Science and Technology, 9 (2 (31)), 18-25. doi: 10.15673/2073-8684.31/2015.44263

[9] Cherno, N., Kapustyan, A. (2016). Immunological properties of the bacterial origin compounds. Food science and technology, 10 (3), 19-28. doi: 10.15673/fst.v10i3.175

[10] Simova, E., Beshkova, D. (2007). Effect of growth phase and growth medium on peptidase activities of starter lactic acid bacteria. Le Lait, 87 (6), 555-573. doi: 10.1051/lait:2007036

[11] Wood, B. J., Warner, P. J. (Ed.) (2012). Genetics of Lactic Acid Bacteria. Berlin: Springer, 394.

[12] Semak, I. V., Zyryanova, T. N., Gubich, O. I. (2007). Biohimiya belkov. Minsk: BSU, 49.

[13] Gavrilin, M. V., Sen'chukova, G. V., Senchenko, S. P. (2007). Vybor optmal'nyh uslovii po» lucheniya gidrolizatov molochnokislyh bakterii termokislotnym sposobom. Himiko-farmatsevticheskiy zhurnal, 41 (2), 54-56.

[14] MMG 2332013 Genetics \& Genomics Wiki. Available at: http://mmg-233-2013-genetics-genoz mics.wikia.com/wiki/File: Ion-exchange_column.jpg

[15] Striegel, A. M., Yau, W. W., Kirkland, J. J., Bly, D. D. (2009). Development and detection of size separation by SEC. Modern Size-Exclusion Liquid Chromatography - Practice of Gel Permeation and Gel Filtration Chromatography. doi: 10.1002/9780470442876 